NBER WORKING PAPER SERIES

\title{
WHY IS AN ELITE UNDERGRADUATE EDUCATION VALUABLE? EVIDENCE FROM ISRAEL
}

\author{
Kevin Lang \\ Erez Siniver \\ Working Paper 16730 \\ http://www.nber.org/papers/w16730 \\ NATIONAL BUREAU OF ECONOMIC RESEARCH \\ 1050 Massachusetts Avenue \\ Cambridge, MA 02138 \\ January 2011
}

We are grateful to Hebrew University and to the College of Management Academic Studies for their assistance with this project. We also thank participants in lunch-time workshops at Boston University and MIT, and at the ASSA and EALE/SOLE meetings for helpful comments and suggestions. The views expressed herein are those of the authors and do not necessarily reflect the views of the National Bureau of Economic Research.

NBER working papers are circulated for discussion and comment purposes. They have not been peerreviewed or been subject to the review by the NBER Board of Directors that accompanies official NBER publications.

(C) 2011 by Kevin Lang and Erez Siniver. All rights reserved. Short sections of text, not to exceed two paragraphs, may be quoted without explicit permission provided that full credit, including $\odot$ notice, is given to the source. 
Why Is an Elite Undergraduate Education Valuable? Evidence from Israel

Kevin Lang and Erez Siniver

NBER Working Paper No. 16730

January 2011

JEL No. I21,J24,J3

\begin{abstract}
$\underline{\text { ABSTRACT }}$
In this paper we compare the labor market performance of Israeli students who graduated from one of the leading universities, Hebrew University (HU), with those who graduated from a professional undergraduate college, College of Management Academic Studies (COMAS). Our results support a model in which employers have good information about the quality of HU graduates and pay them according to their ability, but in which the market has relatively little information about COMAS graduates. Hence, high-skill COMAS graduates are initially treated as if they were the average COMAS graduate, who is weaker than a HU graduate, consequently earning less than UH graduates. However, over time the market differentiates among them so that after several years of experience, COMAS and HU graduates with similar entry scores have similar earnings. Our results are therefore consistent with the view that employers use education information to screen workers but that the market acquires information fairly rapidly.
\end{abstract}

Kevin Lang

Department of Economics

Boston University

270 Bay State Road

Boston, MA 02215

and NBER

lang@bu.edu

Erez Siniver

College of Management

Rishon LeZion, Israel

sinivr@colman.ac.il 


\section{Introduction}

Most studies find positive effects of attending an elite tertiary institution. Graduating from an elite university is generally associated with higher wages, and those attending such universities are both more likely to graduate and to go on to post-graduate study. Yet, doubts persist as to whether such effects are truly causal or merely reflect our imperfect ability to control for differences between students who attend different universities. Most recent studies have relied either on extensive regression controls or on some form of matching and thus must assume that there is no selection on unobservables. In the literature review below, we question this assumption, as do many of the authors whose work we review.

Perhaps more importantly from our perspective, virtually all of the studies simply address whether students benefit from attending elite institutions and not on distinguishing the mechanisms that generate benefits. Yet, there are multiple pathways by which students might gain. Elite institutions might provide higher quality instruction. In the United States, top liberal arts colleges might hire the best instructors and students at leading research institutions might benefit from being taught by top researchers in their fields. There might be important peer effects. Courses at elite institutions may be taught at a higher level because students at these institutions are more capable of handling difficult material. Students may learn directly from interaction with peers, both inside and outside the university. Or, these peers may help each other in the labor market, especially after they have established themselves, by creating effective networks. Finally, students near the admissions cutoff may benefit from statistical discrimination or the signaling value of their elite education. The market may infer that, among apparently similar graduates, those who attended an elite institution have better unobserved characteristics.

In this paper we compare students in Israel who attended one of the leading universities, Hebrew University (HU), with those who attended a professional undergraduate college, College of Management Academic Studies (COMAS). The data were collected in 1999 and 2001 and cover students who graduated in the late 1980s and 1990s. To understand why this comparison is interesting and helps address the issues discussed above, we must consider the institutional setting. Entry into HU is largely formulaic. Each department sets a cutoff entry requirement 
based on the bagrut (high school exit exam) and a psychometric test similar to the SAT. All students above that cutoff are admitted to the program. There is a small range below the cutoff in which students may be admitted if space remains and a very small possibility for the head of the department or program to make exceptions.

As a result, the probability of being admitted to HU increases dramatically as the student's test scores go from slightly below the cutoff to slightly above it. Moreover, most students who were admitted to HU chose to attend rather than to go to COMAS. HU is both more prestigious and less expensive since COMAS is private while HU is heavily subsidized by the government. During the period we study, the tuition at HU was about \$2,400 compared with about $\$ 6,000$ at COMAS.

COMAS offered degrees in law, economics, accounting and management, all of which were also offered at HU. For each of these fields, we know each student's entry score. Therefore, it is possible to compare outcomes for COMAS and HU graduates while controlling for a polynomial in entry score.

If all we could learn from this study is whether HU students do better, controlling for initial characteristics, than do COMAS students, it would probably be of little interest outside of Israel. However, the comparison also allows us to cast light on the mechanisms underlying any "elite institution benefit" that we may find. In particular, it is unlikely that outcome differences reflect differences in the quality of instruction.

COMAS was founded in 1978. Initially almost all courses were taught by university faculty. During the period we cover, most courses continued to be taught by such faculty, and most of the remainder were taught by COMAS faculty who also had lecturer appointments at a university. ${ }^{1}$ Because COMAS sought to establish educational parity with Israel's leading universities, for a large fraction of the courses, the syllabus and exams were (and still are) identical at the two institutions at which the instructor teaches. In EC 101, for example, even

\footnotetext{
${ }^{1}$ Initially over 75 percent of COMAS faculty in law and in economics came from Hebrew University. In management and accounting over $75 \%$ came from either HU or Tel Aviv University (private communication from the secretary to the Dean).
} 
today COMAS administers a single exam to multiple sections, and that exam is coordinated by a professor from HU. In some areas, COMAS continues to wait until HU has announced its exam schedule and then schedules exams at the same time, knowing that the exams will be identical. This is emphasized in a recent report on the economics program at COMAS by the Committee for the Evaluation of Economics Study-Programs [in Israel]:

... faculty members said that, while they would prefer to offer more applied courses, they were bound to follow the syllabi set by the research universities; to do otherwise would penalize their students. (Helpman et al, 2008, p. 6)

However, on the previous page, the Committee does note that "[t]he variance in levels of student ability was mentioned several times as a weakness, holding back to some extent instructors in classes and leading to compromises in the level of instruction." To the extent that there is any difference in the quality of instruction, we would expect it to work in favor of COMAS students because classes at the College tend to be noticeably smaller than at HU. So if there are benefits to attending the more elite institution, they must come from one of the three mechanisms noted above. Moreover, completion rates at both institutions are very high, so that selection on this dimension is unlikely to be important.

None of the explanations fits the data perfectly, and they are not mutually exclusive. However, our results are most consistent with a model in which employers have good information about the quality of HU graduates and pay them according to their ability, but in which the market has relatively little information about COMAS graduates so that their return to skill increases over time. Because COMAS graduates are, on average, weaker, they earn less, on average, than do HU graduates. Initially high skill COMAS graduates are treated as if they were the average COMAS graduate, but over time the market differentiates among them so that after several years of experience, COMAS and HU graduates with similar entry scores have similar earnings.

Our results are therefore consistent with the view that employers use education information to screen workers but that the market acquires information fairly rapidly (Lange, 
2007). The results for HU are consistent with the general finding for the United States that the market can infer the pre-college skills of college graduates (Arcidiacono, Bayer and Hizmo, 2010). Since COMAS was relatively new at the time of our study, the market may have been less able to assess its graduates.

\section{Literature Review}

Because students who attend more elite institutions are probably more able than those who do not, all recent studies attempt to use statistical techniques to control for differences in student quality. Many studies rely on linear regression, although some have used matching techniques, and Long (2008) uses the quality of nearby colleges as an instrument. Brand and Halaby (2006) find little difference between the results they obtain using the regression and matching, but Black and Smith (2003) find smaller (and statistically insignificant effects) when they use matching instead of linear regression. Black and Smith (2006) find that the estimated benefits increase when multiple measures are used to determine quality.

Most studies find that students benefit from attending elite universities. Most of the benefit is measured in terms of labor market outcomes (Loury and Garman, 1995; Brewer, Eide and Ehrenberg, 1999; Chevalier and Conlon, 2003; Black and Smith, 2005; Black and Smith, 2006; Brand and Halaby, 2006; Long, 2008), but there is also an important effect on postgraduation education (Eide, Brewer and Ehrenberg, 1998). There are, however, important exceptions. Perhaps best known is the paper by Dale and Krueger (2002) who find that students gain from attending more expensive but not more selective institutions.

All such studies are subject to the inevitable concern that they have over- or undercontrolled for differences between the students who attend elite and other institutions. Elite American colleges and universities claim to be seeking students who have important noncognitive traits such as leadership, passion and creativity. If they are truly successful in identifying students with these traits, then we would not be surprised if their students had better labor market outcomes than students with similar test scores attending less selective universities. 
On the other hand, Dale and Krueger compare students admitted to similar institutions but who made different decisions about which to attend. But those who chose the weaker institution may have received more merit aid there, indicating that they are, in fact, stronger students.

Even if we accept the general finding that an elite education improves post-graduation outcomes, the literature provides little evidence regarding the source of the effect. Dills and Hernandez-Julien (2008) find that Clemson University students who transfer introductory course credits from higher quality institutions perform better in their intermediate classes, but the effect is small.

As noted above, the benefits of an elite university education may come through peer effects. This literature is extensive, and we cannot do it full justice in a brief review. Most research on this topic focuses on school-age children (Hoxby, 2000; Hanushek, Kain and Rivkin, 2002; Hanushek et al, 2003; Angrist and Lang, 2004; Ammermueller and Pischke, 2009; Gould, Lavy and Paserman, 2009), and the findings have been very mixed. ${ }^{2}$

The literature on peer effects in higher education is much less extensive. Arcidiacono and Nicholson (2005) use random variation in the quality of cohorts within medical schools and find evidence of at most very modest peer effects. In contrast, Sacerdote (2001) and Winston and Zimmerman (2003) find some evidence of effects of randomly assigned college roommates on each other's academic performance. Carrell, Fullerton and West (2009) find benefits from random assignment to a squadron with better peers, but using an actual intervention, Carrell, Sacerdote and West (2010) warn that low performers may actually be disadvantaged if they are assigned to a very heterogeneous group. In contrast, at the elementary school level, Imberman, Kugler and Sacerdote (2009), find positive albeit nonlinear effects of good peers for all children. None of these studies addresses differences at the level of the institution.

Where the individual studies may also affect wages through statistical discrimination (Phelps, 1972, formalized in Aigner and Cain, 1977). The evidence suggests that employers use

\footnotetext{
${ }^{2}$ There is also a notable literature that uses experimental and quasi-experimental techniques to examine the effect of neighborhood on outcomes (Katz, Kling and Liebman, 2001; Oreopoulos, 2003; Jacob, 2004, Sanbonmatsu et al, 2006).
} 
educational attainment to screen workers (Lang, 1986; Bedard, 2001), but that the market learns about worker productivity over time (Farber and Gibbons, 1996; Altonji and Pierret, 2001) and possibly quite quickly (Lange, 2007).

Finally, peers may be a source of information about jobs (Granovetter, 1974) or about workers (Montgomery, 2001). ${ }^{3}$ Holzer (1996) documents the extensive use of networks in hiring in low-skill labor markets. We will be examining high-skill labor markets where networks might be expected to play a lesser role, but it should be recalled that Granovetter's study focused on professional workers in a Boston suburb. Moreover, anyone who has participated in the academic labor market for new $\mathrm{PhD}$ economists is well aware of the role of networks even in a setting where potential employers should be able to judge quality fairly accurately and information about job openings is readily available.

\section{Theory and Methods}

As discussed in greater detail below, we have data on the performance of Hebrew University and College of Management Academic Sciences graduates before, during and after university/college. We use these data to examine whether which institution a student attends affects his or her outcomes and, if so, through what channel.

Peer effects on learning

Although we have argued that the formal education is similar at COMAS and HU, informal learning may be quite different. HU students may benefit more from discussions with classmates, study sessions, etc. On the other hand, classes at COMAS tend to be smaller, and this may help its students. Also, in contrast with HU, most core courses at COMAS have two hours of teaching-assistant-led discussion sections in addition to the four hours of lecture that are standard at both institutions. If we find that students at HU outperform those at COMAS, this will be strong evidence of peer effects on learning. If we find the opposite, then the effect of

\footnotetext{
${ }^{3}$ See Ioannides and Loury (2004) for a more extensive review.
} 
peers is insufficient to outweigh the benefits of smaller class size and more teaching assistant time.

We test for effects on learning in two ways. First, we have data on GPA. We estimate the equation

$$
\mathrm{GPA}=\mathrm{a}+\mathrm{bHU}+\mathrm{f}(\text { entry score })+\mathrm{XB}+\mathrm{e}
$$

where $\mathrm{HU}$ is a dummy variable for whether the individual attended $\mathrm{HU}$ and $\mathrm{f}$ is a quartic in the entry score. The subscripts denoting individuals are dropped for convenience.

One concern about equation (1) is that, contrary to the claims of faculty at COMAS, they may use lower standards for COMAS than for HU students, or faculty who teach only at HU and not at COMAS may be tougher graders than those who also teach at COMAS. Both law and accounting have professional exams that we can use to test this hypothesis. For these two fields we can test the "grade inflation" hypothesis by asking whether COMAS students have higher grades than would be expected on the basis of their performance on the professional exams. Since these exams are graded by a common set of examiners outside of the two institutions, they are not subject to the grade inflation argument.

To test for grade inflation, we therefore estimate

$$
\mathrm{GPA}=\mathrm{a}+\mathrm{b} \mathrm{HU}+\mathrm{c} \text { Prof. Exam Grade }+\mathrm{d} \text { Attempts at Prof. Exam }+\mathrm{XB}+\mathrm{e} .
$$

We choose this "reverse regression" approach because it provides a simple way to control simultaneously for the grade on the exam and the number of times the individual took the professional exam. In the case of accounting, it is easy to control simultaneously for both professional exams.

Equation (2) has no causal interpretation. It is merely a way to test for differences in grading between the two institutions. We can learn more about peer effects on learning by examining the direct effect of the institutions on performance on these exams. We therefore replace GPA as the dependent variable with

$$
\text { Prof. Exam }=a+b \text { HU }+f(\text { entry score })+X B+e
$$


where the left hand side is a measure of performance such as the test score or the number of attempts.

Of course, we must recognize that there may reasons other than peers for differences in outcomes. For example, one of the institutions may put more emphasis on preparing students for the professional exams. However, given the importance of these exams, we find it unlikely that there is a dramatic difference between the two institutions in the centrality accorded to the exams. To the extent that the focus of the two institutions differs, the estimates address whether the peer effects are sufficient to outweigh them.

\section{Labor Market Effects}

If there are effects on learning, we would expect the choice of institution to affect the earnings of graduates. However, to preview the results somewhat, our evidence suggests that COMAS students do as well as HU students on professional exams and have higher GPAs although much of the difference in GPA probably reflects differences in grading standards.

Nevertheless, there may still be differences in earnings between HU and COMAS students. If the market does not have information about the productivity of individual students but does know from which institution they graduated, it will treat individuals as representative of the institution from which they are drawn (Phelps, 1972). In this case, HU graduates will earn more than COMAS graduates do, and in each case, weaker students will benefit from being pooled with stronger students while stronger students will be penalized. Note that in each case, all students would prefer to graduate from HU.

However, we would expect the market to learn gradually about workers' true productivities. The now standard approach (see Lang and Lehmann, 2010, for a discussion) to testing for such effects is to include additional information that may not be readily available to the market. Thus we estimate

$$
\ln \mathrm{w}=\mathrm{XB}+\mathrm{b} H U+\mathrm{c} \text { Entry Score }+\mathrm{d} \text { Exp. }+ \text { f HU*Exp. }+ \text { g Entry Score*Exp. }
$$

If the market does not know or does not use the entry score information, then the estimate of $\mathrm{c}$ will be zero and $\mathrm{b}$ will capture the difference in average productivity between the two 
groups. After the market has had time to learn about workers' true productivities, the effect of HU on earnings should be 0 while entry score should have a positive effect.

If the effect of attending $\mathrm{HU}$ does not go to zero over time, then either firms are not profit maximizing or there must be a direct benefit of attending HU. Perhaps there is learning not captured by GPA or professional tests or HU students benefit from better networks.

However, networks are often modeled as a source of information about workers. If HU students have better networks than COMAS students do, we would expect HU students to receive greater rewards initially for their own productivity while COMAS students would be treated more like the average of their group. This suggests a more general specification

$$
\ln w=X B+b_{1} H+b_{2} E+b_{3} S+b_{4} H^{*} E+b_{5} E^{*} S+b_{6} H^{*} S+b_{7} H^{*} E^{*} S+e
$$

where $\mathrm{H}$ refers to $\mathrm{HU}$ graduates, $\mathrm{E}$ is experience, $\mathrm{S}$ is the entry score. This specification nests a large number of models. If learning is unimportant, than the coefficients on all the interaction terms should be zero. If learning is similarly important for HU and COMAS graduates, then the coefficients on the last two interactions should be zero. In the extreme case, where HU graduates had good networks that fully revealed their productivity and the market has no information about recent COMAS graduates, $b_{3}$ and $b_{6}$ would be zero. In practice, when we use the full sample, we include experience squared and experience squared interacted with being an HU graduate.

\section{Data}

At the time of our study, COMAS graduated students in four major areas: accounting, management, economics and law. In 1999 both institutions graciously agreed to send questionnaires to a random sample of their graduates. We provided questionnaires in sealed envelopes, and administrative assistants at each institution were asked to select students at random based on an algorithm we provided. The sample was supposed to be limited to students who graduated between 1993 and 1998. We allowed replacement sampling for the modest number of envelopes that were returned as undeliverable. 
Unfortunately, we learned from the administrative assistant at COMAS that a new secretary had misunderstood the instructions and sent some of the surveys to students who graduated in earlier years. Fortunately, we made this discovery sufficiently early that we were able to ask the HU administrative assistant to alter the sampling procedure to match that of COMAS. As a result, for both institutions we have a small number of respondents who graduated in the late 1980s and early 1990s. For reasons we do not understand but which may be related to the same secretarial error, COMAS graduates from 1997 are noticeably over-represented in the sample. With this exception, the distribution of respondents across years is similar for HU and COMAS. A total of 600 surveys were returned for a response rate of roughly 38 percent of those for whom the letter was not returned as undeliverable.

In 2001, we sent a further 600 surveys to students who graduated between 1996 and 1999. Of these, 220 were returned. Four report graduating in 1995 and eleven in 2000.

Otherwise, the results are consistent with proper sampling. We do not know whether the "illegal responses" represent reporting error or inappropriate selection of the sample, but the distributions of the samples across graduation years are the same for COMAS and HU, suggesting that the issue is not secretarial error. Fully 97 percent of our sample reports graduating in the period 1991 to 1999.

COMAS provided us with information on average scores on the bagrut and psychometric test by major for 1993 - 1998 which covers over 80 percent of our sample. This allows us to compare our sample with the student universe. Unfortunately, we were not able to obtain similar information from HU. In addition, we used administrative records from COMAS and HU to determine the average GPA and approximate number of graduates by major at each institution for this period.

Our survey asked respondents about their pre-admission records (school-leaving exams known as the bagrut and psychometric test scores), their performance at university (GPA), their performance on professional exams, if any, and their current salary. In addition, the survey collected basic demographic information. 
In order to verify whether our sample is representative, we compare (see table 1) reported student performance (before, during and after college or university) with the means in the administrative records. For accounting and management, the confidence intervals for the sample means include the means in the administrative records for all three measures at COMAS and the single measure at HU. However, at both COMAS and HU, reported grades and pre-entry scores for economists and lawyers are somewhat higher for the sample than recorded in administrative records. We do not know whether this reflects non-random response, changes in student quality over time or a tendency for economists and lawyers to exaggerate their performance. While statistically significant, none of the discrepancies is large. We take this as some evidence that we do not have significant sample selection bias either from nonrandom response or from the difficulties in the drawing of our sample.

Table 2 summarizes the data. The sample is roughly evenly divided among the four fields and between students who attended COMAS and those who attended HU. Respondents who attended the College report lower entry credentials (65 points on the aptitude test and .72 points on the end-of-school exams). They also report lower scores on the professional exams and lower earnings. Hebrew University graduates are noticeably more likely to gain an advanced degree and somewhat more likely to be in government employment although this latter difference falls short of significance at the .05 level. Levels of public sector non-government employment are similar.

We note that all members of our sample report a wage. Given the nature of our population, this is somewhat, but not very, surprising. In the 2002 Social Survey, although only $80 \%$ of 30-34 year olds with a college/university degree report work as their main activity last week, $95 \%$ were in some form of paid employment. ${ }^{4}$ Given that our population attended relatively elite institutions and studied employment-related fields, we would expect the proportion engaged in some form of paid employment to be even higher. This is consistent with a COMAS alumni survey which found employment rates well above 90 percent (personal

\footnotetext{
${ }^{4}$ Authors calculations using table generator at http://surveys.cbs.gov.il/Survey/surveyE.htm.
} 
communication from the secretary to the Dean). Still, the absence of any respondents who do not report a wage is consistent with some positive selection into our sample

It is worth noting that there is considerable variation across the fields in pre-university or pre-college performance. Law students show much higher entry scores than students in the other fields while economics students have the weakest entry credentials.

\section{Results}

\section{Entry Score and University Attendance}

From our discussions with relevant individuals, we understand that each year each department at the University and College selects target entry requirements based on the bagrut and psychometric exam. These requirements are, at first blush, complex combinations of results

for the two exams. For example, in a recent year, Hebrew University published the following requirements for entry into the economics program - at least 448 on the psychometric exam and 11.00 on the bagrut or at least 502 on the psychometric exam and at least 10.50 on the bagrut or at least 556 on the psychometric exam and at least 10.00 on the bagrut or at least 582 on the psychometric exam and at least 9.75 on the bagrut, or at least 771 on the psychometric exam and at least 8.00 on the bagrut.

As published, the cutoffs seem to be discrete approximations to what are essentially linear formulas. In the example above, the cutoffs in the table satisfy the formula $108 *$ bagrut + psychometric $\geq 1558$. For other years and other majors, the linear relation is not perfect, but it is generally very close. For the period for which we have data, the entry requirement is always well approximated by the rule $100 *$ bagrut + psychometric is greater than some cutoff.

Strikingly, in recent years this approximation has changed. Some fields, such as economics, use a tradeoff of 108 points on the psychometric exam for 1 point on the bagrut. Others, including management, accounting and law use a tradeoff of 46 or 47 points.

Our approach depends on the existence of a relatively sharp cutoff above which students are admitted to and attend the University and below which they attend the College. In fact, all 
126 students with scores above 1693 attended the University. Similarly, almost all students with low scores attend the College. Of the 131 members of our sample with scores below 1490, only five attended the University.

Of course, there is still a significant range of overlap in which students attend both institutions. However, some of this reflects different standards for entry into the four fields. Figures 1a-1d show the relation by field. Except in economics, the division between students is quite sharp. For the fields other than economics, the overlap between the lowest entry score for an HU graduate and the highest score for a COMAS graduate is less than one hundred points, with the exception of one HU accounting graduate who reports a very low entry score. ${ }^{5}$ Although we have described entry as formulaic and argued that students admitted to both institutions will attend $\mathrm{HU}$, there is still some overlap in the test scores of entrants. This reflects a number of factors. First, the admissions cutoffs change over time. Second, HU departments may admit students up to sixty points below the cutoff. Third, COMAS provides some scholarship money in an attempt to attract stronger students. Fourth, some students might have failed to qualify for another university and attended COMAS instead. ${ }^{6}$ And, fifth, respondents may have misreported their scores.

\section{$\underline{\text { Academic Achievement }}$}

We begin by examining the grades of HU and COMAS graduates. The average in the sample ranges from 65 to 98 with a mean of 82 and a standard deviation of 5. If grading policies were truly consistent across institutions and there were no peer effects, we would expect average grades to be similar conditional on entry score and higher at HU not conditional on the entry score.

Unconditionally, grades are slightly higher at HU, by an average of 1.0 points. However, as shown in table 3 , conditional on a quartic in entry score and other controls, they are 4.4 points higher at COMAS. The difference, conditional on entry score, is highest in accounting (5.3

\footnotetext{
${ }^{5}$ Dropping this individual does not affect the results.

${ }^{6}$ COMAS is closer than HU to Tel Aviv, for example. Students who want to live in or near Tel Aviv might have applied to Tel Aviv University and COMAS but not to HU.
} 
points) and lowest in economics (4.1 points). The results (not shown) are similar if we restrict the sample to the overlap range and control for entry score linearly. ${ }^{7}$

There are, of course, at least two interpretations of these results. First, the grade difference may be real in the sense that COMAS students may learn more relative to HU students of similar quality. Or, it may be misleading. Contrary to policy, there may be grade inflation at COMAS relative to HU or instruction at COMAS may focus more on test preparation. HU students may learn more material that is not covered on the test. Carrell and West (2008) find that students who take principles courses from teachers who produce high test grades on a common test actually receive lower scores in subsequent classes.

We can cast some light on this issue by looking at the relation between grades and scores on the professional exams in law and accounting. In table 4 we will look at the more intuitive direct regression of test scores on course grades. However, this regression is complicated by the fact that individuals may take the test more than once. In the second column of table 3 , we therefore look at the reverse regression. For law we regress average grade on the bar exam score, the number of times the respondent attempted the bar exam, and the other controls except for the entry score. The coefficient on the university dummy is slightly negative, indicating that grades at COMAS are higher than would be predicted on the basis of subsequent bar exam performance, but statistically insignificant. For accounting we follow a similar procedure but include scores and number of attempts for both exams.

However, when we restrict our estimates to the overlap sample, ${ }^{8}$ we do find significantly lower grades among HU students conditional on professional exam performance. Thus there is some evidence of grade inflation at COMAS. For this reason, in the remainder of the paper we do not control for grades at university/college.

In table 4 we look directly at the relation between COMAS or HU attendance and test performance. In the first column, we compare test scores controlling for entry score (quartic),

\footnotetext{
${ }^{7}$ Entry scores: 1600-1693 (law), 1420-1605 (economics), 1582-1665 (management), 1570-1635 (accounting); 14201665 (all).

${ }^{8}$ The total overlap sample is 629 . By field the sample sizes are: law (112), economics (130), management (76), accounting (58).
} 
graduation year and demographic characteristics but not number of attempts. The coefficients for the accounting exams are small and statistically insignificant. However, for the bar exam, our results show that COMAS students do significantly (at the .1 level) better than their equivalent counterparts at HU. The coefficient is large, over a third of a standard deviation.

Test scores may be misleading for two reasons. First, students who retake the exam in order to pass inflate the average grades since they report only the final (passing) grade. Second, a referee has suggested that grades are heavily clustered just above the passing level and so there is little important variation in grades to be explained. As the means and standard deviations reported in table 2 show, this description is somewhat exaggerated but maintains an element of truth, particularly for the accounting and auditing exams. Since essentially all COMAS and HU students eventually pass the professional exams, the number of times a student attempts the exam is a good proxy for performance. Therefore in the second column, we look at the number of times students attempted each exam. Our estimates show that HU students are ten percentage points more likely to retake the bar exam, consistent with our finding of poorer performance on this exam as measured by their score. The point estimates suggest that, in contrast, COMAS students are more likely to retake the accounting and auditing exams, but the estimates are too imprecise to permit strong conclusions. In sum, table 4 suggests that in law but not accounting, COMAS students outperform HU students on the professional exam.

If we limit ourselves to the overlap sample, the results are similar except that the differences in law lose statistical significance and HU students become significantly less likely to take the financial accounting exam twice.

In sum, controlling for pre-entry performance, COMAS and HU students perform similarly at least as measured by professional tests and GPA, even allowing for some grade inflation. If there is a university wage premium, it cannot be ascribed to the sorts of skills measured directly by exams.

Performance might be reflected in admission to post-graduate programs. Any differences should be treated with caution since we cannot distinguish between graduates who attend post- 
graduate education because they have been successful and those who seek additional education to compensate for weaker initial performance. That said, the probability of having a second degree is increasing in entry score, suggesting that such degrees should be view positively. As noted earlier, HU graduates are more likely than COMAS graduates are to obtain a second degree. This difference disappears once we control for entry score (not shown). There is some evidence of different time trends among management and accounting graduates in the two institutions, but these differences are not robust.

\section{Earnings}

Table 5 shows the results of regressing the individual's current wage on a dummy for attending $\mathrm{HU}$ and additional controls. The first column shows the coefficient on the HU dummy when we control only for experience and the year of the survey, and when we pool the majors, dummies for three of the majors. Not surprisingly HU graduates earn higher wages overall and within each major. The differences are large and highly significant. Column (2) adds controls for demographics but has little effect on the results.

When we control for a quartic in entry score, the university premium is dramatically reduced overall and is eliminated in law. Although somewhat surprisingly it increases in accounting, the change is not statistically significant at conventional levels. Nevertheless, this somewhat anomalous result raises the concern that the quartic is not appropriately adjusting for pre-entry performance. We therefore replicated the results limiting the sample to those in the overlap range and controlling for entry score only linearly. The results are similar to those shown in column (3) of table 5.

Column (4) adds the professional tests to the specification in column (3). The differential in law is now positive but modest and statistically insignificant at conventional levels. The differential in accounting remains large.

To examine the robustness of these results, we consider a number of alternative specifications (not shown). When we restrict our sample to those in the overlap range and therefore control for entry score only linearly, the coefficients are similar but much less precise. 
Only the wage gap combining all fields reaches statistical significance at the .05 level. Dropping the potentially endogenous covariates, public employment, government employment and second degree has no effect except that the estimated gap in economics in the specification column (3) becomes slightly smaller and statistically insignificant. Finally, we restrict the sample to men in private sector employment. In this case, the coefficient on university in the specification used in column (3) falls to .07 and loses significance when all majors are grouped together. ${ }^{9}$ The gap in economics also declines slightly and loses statistical significance. The point estimate for law graduates in both columns (3) and (4) turns noticeably negative but never achieves statistical significance while the university premium for accounting becomes noticeably larger in these specifications.

To explore the HU/COMAS wage differential in greater detail, we turn to estimation of equation (5) above. This specification allows the differential to vary over time and to depend on the entry score of the graduate. Although we have heretofore specified the dummy variable as "university," for reasons that will become apparent, in one of the interactions, it is easier to specify it as "college." It should be recalled that when the equation is unrestricted, this is just a linear transformation.

The results of estimation of equation (5) are presented in the first column of table 6 . This specification constrains the bagrut and psychometric scores to predict wages in relation to their importance in the entry score. Thus wherever the bagrut/psychometric score enters the equation, it is replaced by the entry score or psychometric score $+100 *$ bagrut.

The point estimate suggests that HU graduates with no experience and a zero entry score earn substantially less than COMAS graduates do. However, the slope of HU earnings with respect to the entry score is significantly higher for HU students. Each point on the entry score is worth $.0024 \log$ points more in current earnings for HU graduates than for COMAS graduates. Together the estimates imply that initially COMAS graduates earn less than HU if their entry score was at least 1388, which is the case for all HU graduates.

\footnotetext{
${ }^{9}$ Due to sample size, we have too much collinearity to estimate all the coefficients when we attempt to control for a quartic in entry score. We therefore control only for a cubic.
} 
In contrast, the coefficient on the entry tests is negative, tiny and statistically insignificant for COMAS graduates. Thus, when dealing with COMAS graduates with no experience, the market seems not to have (or use) information about graduates' skill as measured by their entry score. As in Phelps's model of statistical discrimination, COMAS graduates are treated as indistinguishable from each other and are paid less because on average they are less productive. The greater understanding of differences among HU students than among COMAS students results in lower starting wages for COMAS graduates regardless of ability.

However, over time, the market learns to distinguish among COMAS graduates. The three-way interaction of the entry score information, experience and the college dummy is positive and statistically significant. In contrast, the interaction between the entry score information and experience is negative and statistically insignificant. In other words, we cannot reject the hypothesis that the market has full knowledge of the information contained in the entry score for HU graduates entering the market. However, the market takes more time to learn this information for COMAS graduates. Note that as it does, the market wage for lower ability COMAS graduates will tend to fall, which explains the otherwise somewhat surprising negative coefficients on experience and its square.

Because of the many interaction terms in column (1), it is somewhat difficult to understand how the HU/COMAS differential evolves over time. Figures $2 \mathrm{a}$ and $2 \mathrm{~b}$ present this information visually. After four years of experience, the entry score has a positive effect on earnings for COMAS graduates although the slope remains lower than for HU graduates. At low entry scores, earnings are actually higher for COMAS graduates although this difference is only statistically significant for those with entry scores below about 1565, which includes the majority of COMAS graduates but only about six percent of HU graduates. At scores above about 1765 (earned by about one-ninth HU graduates but no COMAS graduates), the earnings gap is statistically significant in favor of the HU graduates. After seven years, the slopes of the two lines are similar. The point estimates suggest that, after seven years, the earnings of COMAS 
graduates are nontrivially higher but the difference is not statistically significant at any entry score.

The second column restricts the model so that all information contained in the entry score of HU graduates is immediately available to the market and none of this information is immediately available for COMAS graduates. This restriction is not rejected by the data. Not surprisingly, the results are similar to those obtained in the first column. We again find that all predicted wages are initially higher for HU than for COMAS graduates, regardless of entry score. Over time the market gains information about the COMAS graduates so that after about ten years, the coefficients on entry score are similar for the two groups.

It is not obvious that the market and educational institutions should put the same relative weight on pre-entry tests. The third and fourth columns of table 6 relax this assumption. In equation (5) we replace entry score with psychometric test $+\gamma^{*}$ bagrut and estimate $\gamma$ along with other parameters by nonlinear least squares. The estimating equation in column (3) is otherwise identical to that in column (1). Our estimate of $\gamma$ is 69 and is statistically insignificantly different from 100. Not surprisingly the results are similar to those in the first column. The point estimates continue to suggest that the market has good information about HU graduates but little or no information about recent COMAS graduates but acquires information comparable to its initial information about HU graduates within seven years. Again we cannot reject the hypothesis that the market has no knowledge of the information contained in the COMAS graduates' entry scores but has complete knowledge about this information for HU graduates.

The restricted model (column (4)) gives similar results. However, the estimate of $\gamma$ is lower (60) and falls just short of being significantly different from 100 at the .05 level. Although this does not change the interpretation of the results, it is striking that the educational institutions have been putting less weight on the bagrut in recent years.

\section{$\underline{\text { Robustness Checks }}$}

Table 7 reports the results of a number of robustness checks. The first row simply repeats the relevant parameters from column (1) of table 6 . The second row addresses the concern that 
we may be confounding experience with cohort effects. It is possible that earlier cohorts at COMAS were rewarded for their entry scores while more recent ones were not. If anything, the opposite seems to us to be more likely. Nevertheless, because we collected data in both 1999 and 2001, cohort and experience are not perfectly collinear in our data, and we can cast some light on this hypothesis. We allow both the dummy for the later sample and an interaction between the later sample and $\mathrm{HU}$ attendance to multiply the entry score (essentially adding $a b_{8}$ and $b_{9}$ to equation (5)). These coefficients are individually and jointly insignificant, and their inclusion does not noticeably change the other coefficients of interest.

A second concern is that HU graduates may be less likely to work in the private sector and that this sector may have a lower initial return to ability but that the return may grow with experience. There may also be important differences between men and women in the return to ability and its pattern over the life-cycle. Therefore, in the third row, we limit the sample to male private sector workers. We have only 520 observations for this specification. Therefore it is not altogether surprising that the college/experience/entry-score interaction loses statistical significance. Nevertheless, the coefficients change little, and the principal message, that among COMAS graduates there is no effect of entry score on initial wages but that this effect is roughly equal to its value for HU graduates after about seven years of experience, is unchanged.

Although the coefficients on experience squared and its interaction with university attendance are highly significant, we have relatively few years of data, and the results may be dependent on a small number of observations who graduated towards the beginning of our sample. Only about four percent of our sample has more than seven years of experience. We therefore restrict the effect of experience to be linear. The results, shown in the fourth row, are similar to those for the base specification.

In the fifth row, we address the possibility that controlling for the potentially endogenous variables second degree and public and government employment could bias the results. The results again are basically indistinguishable from the baseline results. 
Finally, we estimated the model separately for each major separately. We were able to reject the hypothesis that the coefficients were identical (except for the constant term) for the four majors. We were, however, unable to reject the hypotheses that the coefficients were identical for the two majors with professional exams, law and accounting, and for the two majors without professional exams, economics and management. In the sixth row, we see that there is no evidence that COMAS students in law and accounting benefit less from their entry score. The difference is small and statistically insignificant, as is the "catch-up" coefficient. In contrast, the initial return to entry score is much higher for HU than for COMAS graduates in economics and management, but this difference is eliminated after about five years.

\section{Conclusions}

There seems to be little difference in educational outcomes between students who graduate from HU and those who graduate from COMAS. Performance on professional exams is comparable. While students at COMAS have higher grades than would be expected on the basis of their pre-entry performance, much, and perhaps all, of this difference is attributable to differences in grading standards. Thus our findings are consistent with Helpman et al (2008) who find that the strengths and weaknesses of the education provided by COMAS are in many respects similar to those found at the research universities.

Except for those with a strong interest in higher education in Israel, by itself, this finding would not be of great interest. However, coupled with our results regarding wages, it suggests a great deal about the role of higher education in the labor market. We find that the market knows a great deal about HU graduates entering the market at least in the sense that pre-entry information is captured in their wages. This is consistent with the Arcidiacono, Bayer and Hizmo (2010) finding that the U.S. labor market "knows" the AFQT (Armed Forces Qualifying Test) of college graduates. However, it takes the market about seven years to fully acquire this information about COMAS graduates. Moreover, the market seems to have good information about both COMAS and HU graduates in fields where there is a professional exam but does not 
have good information about COMAS graduates when there is no such exam. We do not wish to push this finding too hard. Insignificant results are easier to find when looking at subsamples, but it is consistent with a model of learning in the labor market.

There are at least two explanations for the U.S. result. The first is that college admissions reflect much of the information captured by AFQT. The market can therefore infer much of this information from where an individual attended college. The second is that there are strong networks between colleges/universities and the market that allowed such information to be conveyed. In all probability both mechanisms are at work. The Israel experience suggests that it takes time for the market to learn how to judge graduates from a relatively new institution. Either the market had insufficient information to judge COMAS transcripts or it lacked networks to capture information about COMAS graduates.

Studies of learning in the labor market in the U.S. rely on the assumption that, even though it predicts productivity, the market does not have access to information about AFQT. Our finding that the bagrut and psychometric scores of graduates predict the performance of COMAS graduates raises the question, also asked about AFQT, as to why employers did not seek this information. There is ample evidence that using AFQT has a "business justification," the current requirement in the United States for practices with disparate impact. We have provided evidence of a similar justification in Israel. We note, however, that the market seems to have been able to gather such information for HU graduates, and therefore possibly for other university graduates, through other mechanisms. It is plausible that employers did not recognize the value of the information for graduates of a relative new college. And, privacy laws prevented COMAS from making such information available directly.

In the end, however, we also note that the market acquired the information fairly quickly, within five to eight years depending on the estimate, a rate consistent with Lange (2007) for the U.S. Hence it is also possible that the benefit from investing in acquiring the information was not large. 
Thus we conclude that our results reinforce the growing consensus in the literature on learning in the labor market that labor market and able to gather much of the information that institutions of higher education have on pre-entry performance and that it is able to glean additional information over a relatively modest period. 


\section{REFERENCES}

Aigner, Dennis, and Glen Cain, "Statistical Theories of Discrimination in Labor

Markets," Industrial and Labor Relations Review, 30 (January 1977): 175-87.

Altonji, Joseph G. and Charles R. Pierret, "Employer Learning and Statistical

Discrimination," Quarterly Journal of Economics, 116 (February 2001): 313-350.

Ammermueller, Andreas and Jörn-Steffen Pischke, "Peer Effects in European Primary

Schools: Evidence from the Progress in International Reading Literacy Study," Journal of Labor

Economics, 27 (July 2009): 315-348.

Angrist, Joshua D. and Kevin Lang, "Does School Integration Generate Peer Effects? Evidence

from Boston’s Metco Program,” American Economic Review, 94 (December 2004): 1613-34.

Arcidiacono, Peter, Patrick Bayer, and Aurel Hizmo, "Beyond Signaling and Human

Capital: Education and the Revelation of Ability," AEJ: Applied Economics, 2 (October 2010), 76-104.

Arcidiacono, Peter and Sean Nicholson, "Peer Effects in Medical School, Journal of Public Economics, 89 (February 2005): 327-350.

Black, Dan A., Kermit Daniel, and Jeffrey A. Smith, \College Quality and Wages in the United States," German Economic Review, 6 (2005): $415\{443$.

Black, Dan.A. and Jeffrey A. Smith, "How Robust is the Evidence on the Effects of College Quality? Evidence from Matching,” Journal of Econometrics, 121 (2003): 99-124.

Black, Dan A. and Jeffrey A. Smith, Estimating the Returns to College Quality with Multiple Proxies for Quality," Journal of Labor Economics 24 (July 2006): 701-728.

Imberman, Scott A., Adriana D. Kugler and Bruce Sacerdote, "Katrina's Children:

Evidence on the Structure of Peer Effects from Hurricane Evacuees," NBER Working Paper No. $15291,2009$.

Bedard, Kelly, "Human Capital versus Signaling Models: University Access and High School Dropouts,” Journal of Political Economy, 109 (August 2001): 749-75. 
Birch, Elisa Rose, Ian Li and Paul W. Miller, “The Influences of Institution Attended and Field of Study on Graduates' Starting Salaries (2008-07)," Australian Economic Review, 42 (March 2009): 42-63.

Brand, Jennie E. and Charles N. Halaby, "Regression and Matching Estimates of the Effects of Elite College Attendance on Educational and Career Achievement, Social Science Research, 35 (September 2006): 749-770.

Brewer, Dominic J., Eric R. Eide and Ronald G. Ehrenberg, "Does It Pay to Attend an Elite Private College, The Journal of Human Resources, 34 (Winter 1999): 105-123.

Carrell, Scott E. and James E. West, "Does Professor Quality Matter? Evidence from Random Assignment of Students to Professors," NBER Working Paper 14081, 2008.

Carrell, Scott E., Richard L. Fullerton and James E. West, “Does Your Cohort Matter? Measuring Peer Effects in College Achievement," Journal of Labor Economics, 273 (July 2009): 439-464.

Carrell, Scott E., Bruce I. Sacerdote and James E. West, "From Natural Variation to Optimal Policy: A Cautionary Tale in How Not to Improve Student Outcomes," unpublished, 2010.

Chevalier, Arnaud and Gavan Conlon, "Does It Pay to Attend a Prestigious University?" IZA Discussion Paper No. 848, 2003.

Dale, Stacy Berg and Alan B. Krueger, "Estimating the Payoff to Attending a More Selective College: An Application of Selection on Observables and Unobservables, Quarterly Journal of Economics, 117 (November 2002): 1491-1528.

Dills, Angela K and Rey Hernandez-Julien, "Transfer College Quality and Student Performance,” Eastern Economic Journal, 34 (Spring 2008): 172-189.

Eide, Eric, Dominic J. Brewer, Ronald G. Ehrenberg, "Does It Pay to Attend an Elite Private College? Evidence on the Effects of Undergraduate College Quality on Graduate School Attendance," Economics of Education Review, 17 (October 1998): 371-376. 
Farber, Henry S. and Robert Gibbons, "Learning and Wage Dynamics," Quarterly Journal of Economics, 111 (Nov. 1996): 1007-48.

Gould, Eric D., Victor Lavy and Daniele Paserman, "Does Immigration Affect the LongTerm Educational Outcomes of Natives? Quasi-Experimental Evidence,'Economic Journal, 119 (October 2009): 1243-1269.

Granovetter, Mark S., Getting a Job: A Study of Contacts and Careers. Cambridge, Mass.: Harvard University Press, 1974.

Hanushek, Eric A., John F. Kain and Steven G. Rivkin, "New Evidence about Brown v. Board of Education: The Complex Effects of School Racial Composition on Achievement," NBER Working Paper No. 8741, 2002.

Hanushek, Eric A, John F. Kain, Jacob M. Markman, and Steven G. Rivkin, “Does Peer Ability Affect Student Achievement?" Journal of Applied Econometrics, 18 (September/October 2003): 527-544.

Helpman, Elhanan et al, "The College of Management Academic Studies: Evaluation Report," Council for Higher Education, Israel, 2008.

Holzer, Harry, What Employers Want: Job Prospects for Less-Educated Workers, New York: Russell Sage Foundation, 1996.

Hoxby, Caroline M, "Peer Effects in the Classroom: Learning from Gender and Race Variation,” NBER Working Paper No. 7867, 2000.

Ioannides, Yannis M. and Linda Datcher Loury, “Job Information Networks, Neighborhood Effects, and Inequality," Journal of Economic Literature, 42 (December 2004): 1056-93.

Jacob, Brian A. "Public Housing, Housing Vouchers and Student Achievement: Evidence from Public Housing Demolitions in Chicago," American Economic Review 94 (March 2004): 233-258. 
Katz, Lawrence F., Jeffrey R. Kling, and Jeffrey B. Liebman, "Moving to Opportunity in Boston: Early Results from a Randomized Mobility Experiment," Quarterly Journal of Economics 116 (May 2001): 607-654.

Lang, Kevin, "Human Capital versus Sorting: The Effects of Compulsory Attendance Laws," Quarterly Journal of Economics, 101 (August 1986): 609-24.

Lange, Fabian, “The Speed of Employer Learning," Journal of Labor Economics, 25 (January 2007): 1-35.

Lefgren, Lars. "Educational Peer Effects and the Chicago Public Schools," Journal of Urban Economics, 56 (September 2004): 169-191.

Long, Mark C. “College Quality and Early Adult Outcomes, Economics of Education Review, 27 (October 2008): 588-602.

Loury, Linda Datcher and David Garman, “College Selectivity and Earnings," Journal of Labor Economics, 13 (April 1995): 289-308.

Montgomery, James D., "Social Networks and Labor-Market Outcomes: Toward an Economic Analysis,” American Economic Review, 81 (December 1991): 1408-1418.

Oreopoulos, Philip, “The Long-Run Consequences of Living in a Poor Neighborhood,” Quarterly Journal of Economics, 118 (November 2003): 1533-1575.

Phelps, Edmund, "The Statistical Theory of Racism and Sexism," American Economic Review, 62 (September 1972): 659-61.

Sacerdote, Bruce, "Peer Effects with Random Assignment: Results for Dartmouth Roommates,” Quarterly Journal of Economics, 116 (May 2001): 681-704.

Sanbonmatsu, Lisa, Jeffrey Kling, Greg Duncan and Jeanne Brooks-Gunn, "Neighborhoods and Academic Achievement: Results from the Moving to Opportunity Experiment." National Bureau of Economic Research: Working Paper 11909, 2006.

Winston, Gordon C. and David J. Zimmerman, "Peer Effects in Higher Education," NBER Working Paper 9501, 2003. 
TABLE 1

Comparison of Survey and Administrative Data

\begin{tabular}{|c|c|c|c|c|}
\hline & Undergrad GPA & Bagrut & Psychometric & Bar Exam \\
\hline \multicolumn{5}{|c|}{ College of Management } \\
\hline Law & $*$ & $*$ & * & \\
\hline Survey & 82.4 & 9.80 & 630 & 77.0 \\
\hline Administrative & 81.0 & 9.65 & 623 & 78.0 \\
\hline Economics & $*$ & $*$ & * & \\
\hline Survey & 82.0 & 8.96 & 582 & \\
\hline Administrative & 81.0 & 8.60 & 570 & \\
\hline \multicolumn{5}{|l|}{ Accounting } \\
\hline Survey & 81.0 & 8.94 & 620 & \\
\hline Administrative & 81.2 & 8.88 & 615 & \\
\hline \multicolumn{5}{|l|}{ Management } \\
\hline Survey & 82.3 & 8.97 & 610 & \\
\hline Administrative & 83.0 & 8.95 & 610 & \\
\hline \multicolumn{5}{|c|}{ Hebrew University } \\
\hline Law & $*$ & & & \\
\hline Survey & 83.3 & & & 80.7 \\
\hline Administrative & 82.0 & & & 80.6 \\
\hline Economics & * & & & \\
\hline Survey & 83.0 & & & \\
\hline Administrative & 81.0 & & & \\
\hline \multicolumn{5}{|l|}{ Accounting } \\
\hline Survey & 82.1 & & & \\
\hline Administrative & 82.0 & & & \\
\hline \multicolumn{5}{|l|}{ Management } \\
\hline Survey & 83.3 & & & \\
\hline Administrative & 82.5 & & & \\
\hline
\end{tabular}


TABLE 2

Sample Characteristics

\begin{tabular}{|c|c|c|c|c|c|c|}
\hline & Law & Economics & Management & Accounting & University & College \\
\hline University** & $\begin{array}{c}0.48 \\
(0.50)\end{array}$ & $\begin{array}{c}0.55 \\
(0.50)\end{array}$ & $\begin{array}{c}0.49 \\
(0.50)\end{array}$ & $\begin{array}{c}0.55 \\
(0.50)\end{array}$ & 1.00 & 0.00 \\
\hline $\begin{array}{l}\text { Psychometric } \\
\text { Test** }\end{array}$ & $\begin{array}{l}662 \\
(48)\end{array}$ & $\begin{array}{l}617 \\
(59)\end{array}$ & $\begin{array}{l}645 \\
(54)\end{array}$ & $\begin{array}{l}659 \\
(51)\end{array}$ & $\begin{array}{l}676 \\
(47)\end{array}$ & $\begin{array}{l}611 \\
(44)\end{array}$ \\
\hline Bagrut** & $\begin{array}{c}9.97 \\
(0.41)\end{array}$ & $\begin{array}{c}9.37 \\
(0.63)\end{array}$ & $\begin{array}{c}9.43 \\
(0.72)\end{array}$ & $\begin{array}{c}9.47 \\
(0.80)\end{array}$ & $\begin{array}{c}9.89 \\
(0.46)\end{array}$ & $\begin{array}{c}9.18 \\
(0.73)\end{array}$ \\
\hline $\begin{array}{l}\text { College/Univ. } \\
\text { GPA** }\end{array}$ & $\begin{array}{l}82.9 \\
(4.5)\end{array}$ & $\begin{array}{l}82.6 \\
(5.0)\end{array}$ & $\begin{array}{l}82.8 \\
(5.0)\end{array}$ & $\begin{array}{l}81.6 \\
(5.3)\end{array}$ & $\begin{array}{l}82.9 \\
(4.9)\end{array}$ & $\begin{array}{l}82.0 \\
(5.0)\end{array}$ \\
\hline $\begin{array}{l}\text { CPA/Bar Exam } \\
\text { Score** }\end{array}$ & $\begin{array}{l}78.8 \\
(8.4)\end{array}$ & - & & $\begin{array}{l}69.1 \\
(6.8)\end{array}$ & $\begin{array}{l}75.0 \\
(9.2)\end{array}$ & $\begin{array}{l}72.5 \\
(8.7)\end{array}$ \\
\hline $\begin{array}{l}\text { Auditing Exam } \\
\text { Score** }\end{array}$ & - & - & & $\begin{array}{l}67.1 \\
(7.2)\end{array}$ & $\begin{array}{l}68.5 \\
(8.0)\end{array}$ & $\begin{array}{r}65.4 \\
(5.7)\end{array}$ \\
\hline $\begin{array}{l}\text { ln Current } \\
\text { Wage** }\end{array}$ & $\begin{array}{c}9.30 \\
(0.47)\end{array}$ & $\begin{array}{c}9.16 \\
(0.39)\end{array}$ & $\begin{array}{c}9.39 \\
(0.35)\end{array}$ & $\begin{array}{c}9.52 \\
(0.44)\end{array}$ & $\begin{array}{c}9.47 \\
(0.42)\end{array}$ & $\begin{array}{c}9.20 \\
(0.41)\end{array}$ \\
\hline Age & $\begin{array}{l}30.7 \\
(3.0)\end{array}$ & $\begin{array}{l}29.3 \\
(3.2)\end{array}$ & $\begin{array}{l}31.0 \\
(3.4)\end{array}$ & $\begin{array}{l}32.0 \\
(3.2)\end{array}$ & $\begin{array}{l}30.9 \\
(3.1)\end{array}$ & $\begin{array}{l}30.6 \\
(3.6)\end{array}$ \\
\hline Male & $\begin{array}{c}0.57 \\
(0.50)\end{array}$ & $\begin{array}{c}0.63 \\
(0.48)\end{array}$ & $\begin{array}{c}0.65 \\
(0.48)\end{array}$ & $\begin{array}{c}0.69 \\
(0.46)\end{array}$ & $\begin{array}{c}0.65 \\
(0.48)\end{array}$ & $\begin{array}{c}0.62 \\
(0.48)\end{array}$ \\
\hline Native & $\begin{array}{c}0.89 \\
(0.32)\end{array}$ & $\begin{array}{c}0.85 \\
(0.35)\end{array}$ & $\begin{array}{c}0.88 \\
(0.32)\end{array}$ & $\begin{array}{c}0.88 \\
(0.33)\end{array}$ & $\begin{array}{c}0.86 \\
(0.35)\end{array}$ & $\begin{array}{c}0.89 \\
(0.31)\end{array}$ \\
\hline Russian Father & $\begin{array}{c}0.06 \\
(0.24)\end{array}$ & $\begin{array}{c}0.05 \\
(0.22)\end{array}$ & $\begin{array}{c}0.03 \\
(0.16)\end{array}$ & $\begin{array}{c}0.05 \\
(0.22)\end{array}$ & $\begin{array}{c}0.04 \\
(0.20)\end{array}$ & $\begin{array}{c}0.06 \\
(0.24)\end{array}$ \\
\hline $\begin{array}{l}\text { Sephardic } \\
\text { Father** }\end{array}$ & $\begin{array}{c}0.21 \\
(0.41)\end{array}$ & $\begin{array}{c}0.30 \\
(0.46)\end{array}$ & $\begin{array}{c}0.23 \\
(0.42)\end{array}$ & $\begin{array}{c}0.30 \\
(0.46)\end{array}$ & $\begin{array}{c}0.22 \\
(0.42)\end{array}$ & $\begin{array}{c}0.30 \\
(0.46)\end{array}$ \\
\hline Father Other & $\begin{array}{c}0.26 \\
(0.44)\end{array}$ & $\begin{array}{c}0.18 \\
(0.38)\end{array}$ & $\begin{array}{c}0.16 \\
(0.37)\end{array}$ & $\begin{array}{c}0.21 \\
(0.41)\end{array}$ & $\begin{array}{c}0.22 \\
(0.41)\end{array}$ & $\begin{array}{c}0.18 \\
(0.38)\end{array}$ \\
\hline $\begin{array}{l}\text { Government } \\
\text { Employee* }\end{array}$ & $\begin{array}{c}0.17 \\
(0.38)\end{array}$ & $\begin{array}{c}0.16 \\
(0.37)\end{array}$ & $\begin{array}{c}0.12 \\
(0.32)\end{array}$ & $\begin{array}{c}0.13 \\
(0.34)\end{array}$ & $\begin{array}{c}0.17 \\
(0.37)\end{array}$ & $\begin{array}{c}0.12 \\
(0.33)\end{array}$ \\
\hline $\begin{array}{l}\text { Public Sector } \\
\text { Employee }\end{array}$ & $\begin{array}{c}0.15 \\
(0.36)\end{array}$ & $\begin{array}{c}0.31 \\
(0.46)\end{array}$ & $\begin{array}{c}0.34 \\
(0.48)\end{array}$ & $\begin{array}{c}0.20 \\
(0.40)\end{array}$ & $\begin{array}{c}0.25 \\
(0.43)\end{array}$ & $\begin{array}{c}0.25 \\
(0.44)\end{array}$ \\
\hline $\begin{array}{l}\text { Second } \\
\text { Degree** }\end{array}$ & $\begin{array}{c}0.28 \\
(0.45)\end{array}$ & $\begin{array}{c}0.38 \\
(0.49)\end{array}$ & $\begin{array}{c}0.37 \\
(0.48)\end{array}$ & $\begin{array}{c}0.26 \\
(0.44)\end{array}$ & $\begin{array}{c}0.40 \\
(0.49)\end{array}$ & $\begin{array}{c}0.23 \\
(0.42)\end{array}$ \\
\hline $\mathrm{N}$ & 195 & 226 & 190 & 208 & 428 & 391 \\
\hline
\end{tabular}


TABLE 3

Average Grade: University Relative to College

\begin{tabular}{lcc}
\hline & $\begin{array}{c}\text { Controlling for Quartic in } \\
\text { Entry Score }\end{array}$ & $\begin{array}{c}\text { Controlling for Performance on } \\
\text { Professional Exams }\end{array}$ \\
\hline All & -4.36 & \\
Law & $(0.45)$ & -0.93 \\
& -4.66 & $(0.62)$ \\
Economics & $(0.80)$ & \\
& -4.14 & -0.97 \\
Accounting & $(0.99)$ & $(0.73)$ \\
& -5.30 & \\
Management & $(1.07)$ & \\
& -4.93 & \\
All regressions control for year of graduation (dummies), born in Israel, Sephardic, father born in \\
Russia, father Ashkenazi, age, a dummy for the 2001 sample, and sex. "All" also controls for \\
field of graduation.
\end{tabular}


TABLE 4

Performance on Professional Exams: University Relative to College

\begin{tabular}{lcc}
\hline & Test Score & Number of Attempts \\
\hline Bar Exam & -2.88 & 0.10 \\
& $(1.60)$ & $(0.05)$ \\
Financial Accounting & 0.06 & -0.23 \\
& $(1.38)$ & $(0.16)$ \\
Auditing & -0.65 & -0.15 \\
Controls: see table 3. & $(1.22)$ & $(0.19)$
\end{tabular}


TABLE 5

Relation between University Attendance and Earnings

\begin{tabular}{|c|c|c|c|c|}
\hline & (1) & (2) & (3) & (4) \\
\hline All & $\begin{array}{c}0.223 \\
(0.026)\end{array}$ & $\begin{array}{c}0.215 \\
(0.025)\end{array}$ & $\begin{array}{c}0.097 \\
(0.037)\end{array}$ & \\
\hline Law & $\begin{array}{c}0.284 \\
(0.060)\end{array}$ & $\begin{array}{c}0.244 \\
(0.060)\end{array}$ & $\begin{array}{l}-0.002 \\
(0.083)\end{array}$ & $\begin{array}{c}0.076 \\
(0.077)\end{array}$ \\
\hline Economics & $\begin{array}{c}0.274 \\
(0.048)\end{array}$ & $\begin{array}{c}0.288 \\
(0.046)\end{array}$ & $\begin{array}{c}0.127 \\
(0.063)\end{array}$ & \\
\hline Management & $\begin{array}{c}0.150 \\
(0.048)\end{array}$ & $\begin{array}{c}0.150 \\
(0.049)\end{array}$ & $\begin{array}{c}0.114 \\
(0.082)\end{array}$ & \\
\hline Accounting & $\begin{array}{c}0.167 \\
(0.061)\end{array}$ & $\begin{array}{c}0.163 \\
(0.059)\end{array}$ & $\begin{array}{c}0.201 \\
(0.085)\end{array}$ & $\begin{array}{c}0.207 \\
(0.078)\end{array}$ \\
\hline Experience controls & yes & yes & yes & yes \\
\hline Demographic controls & & yes & yes & yes \\
\hline Quartic in Entry Score & & & yes & yes \\
\hline Test score controls & & & & yes \\
\hline
\end{tabular}


TABLE 6

Log Wages, Experience and Test Scores

\begin{tabular}{lcccc}
\hline & \multicolumn{2}{c}{ Entry Score } & \multicolumn{2}{c}{ Bagrut \& Psychometric Test } \\
Separately
\end{tabular}

Also controls for field of graduation, born in Israel, Sephardic, father born in Russia, father other, age, sex, married and married interacted with sex, government employee, public sector employee, second degree and 2001 sample.. 
TABLE 7

Effect of Entry Score on log Wage: College v University by Experience

\begin{tabular}{lcc}
\hline & Entry Score $*$ University & Entry Score*College*Experience \\
\hline Base Model & 0.240 & 0.034 \\
With Cohort Effects & $(0.066)$ & $(0.015)$ \\
& 0.271 & 0.035 \\
Private Sector Male Workers & $(0.071)$ & $(0.015)$ \\
Only & 0.206 & 0.026 \\
Experience Effect Linear & $(0.085)$ & $(0.018)$ \\
& 0.281 & 0.049 \\
Without Potentially & $(0.066)$ & $(0.015)$ \\
Endogenous Covariates & 0.241 & 0.033 \\
Law \& Accounting & $(0.066)$ & $(0.015)$ \\
& 0.058 & -0.001 \\
Economics and Management & $(0.149)$ & $(0.028)$ \\
& 0.331 & 0.068 \\
Coefficients multiplied by 100. For full specification see equation $(5)$ and footnote to table 6.
\end{tabular}


Figure 1a

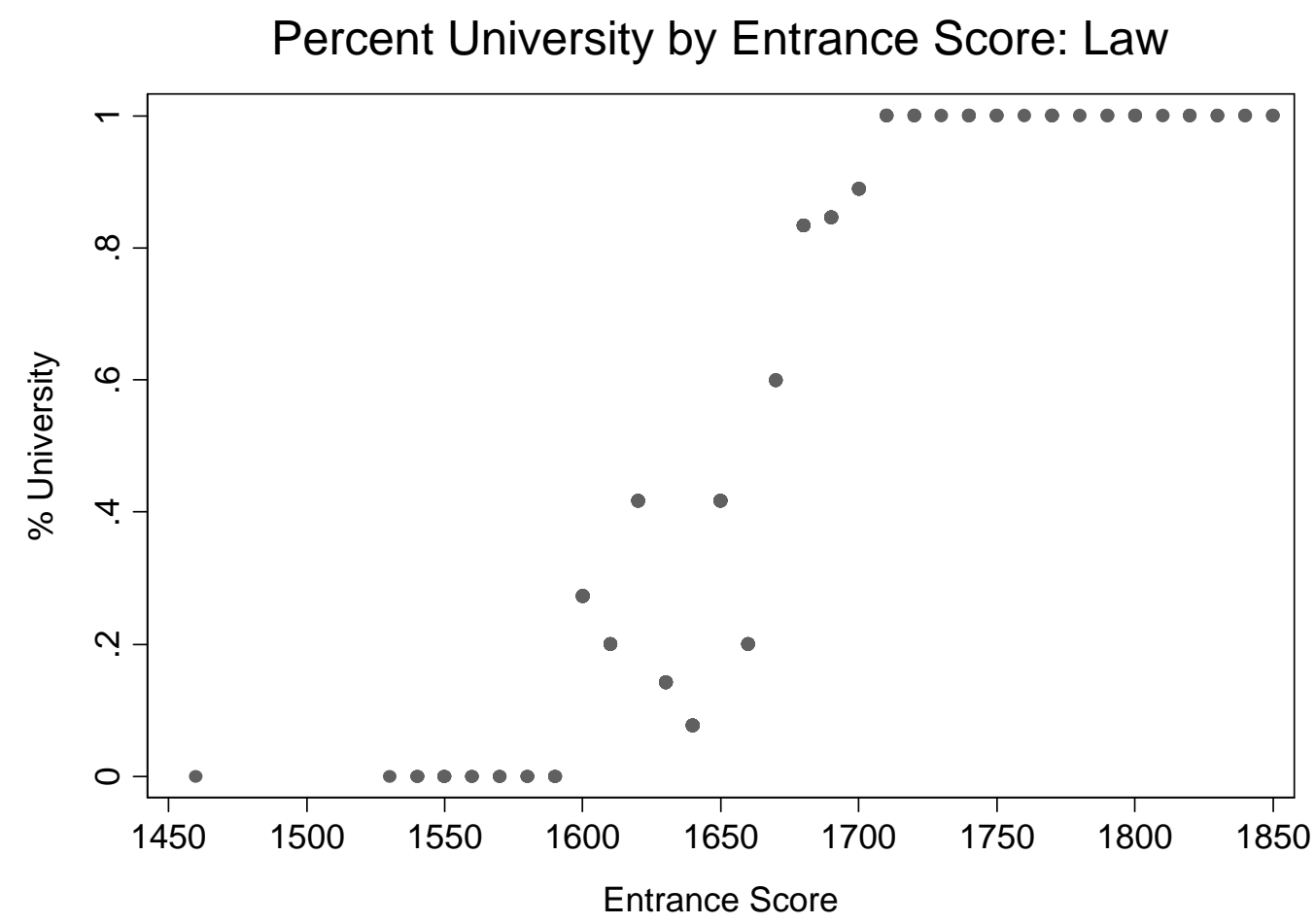

Figure 1b

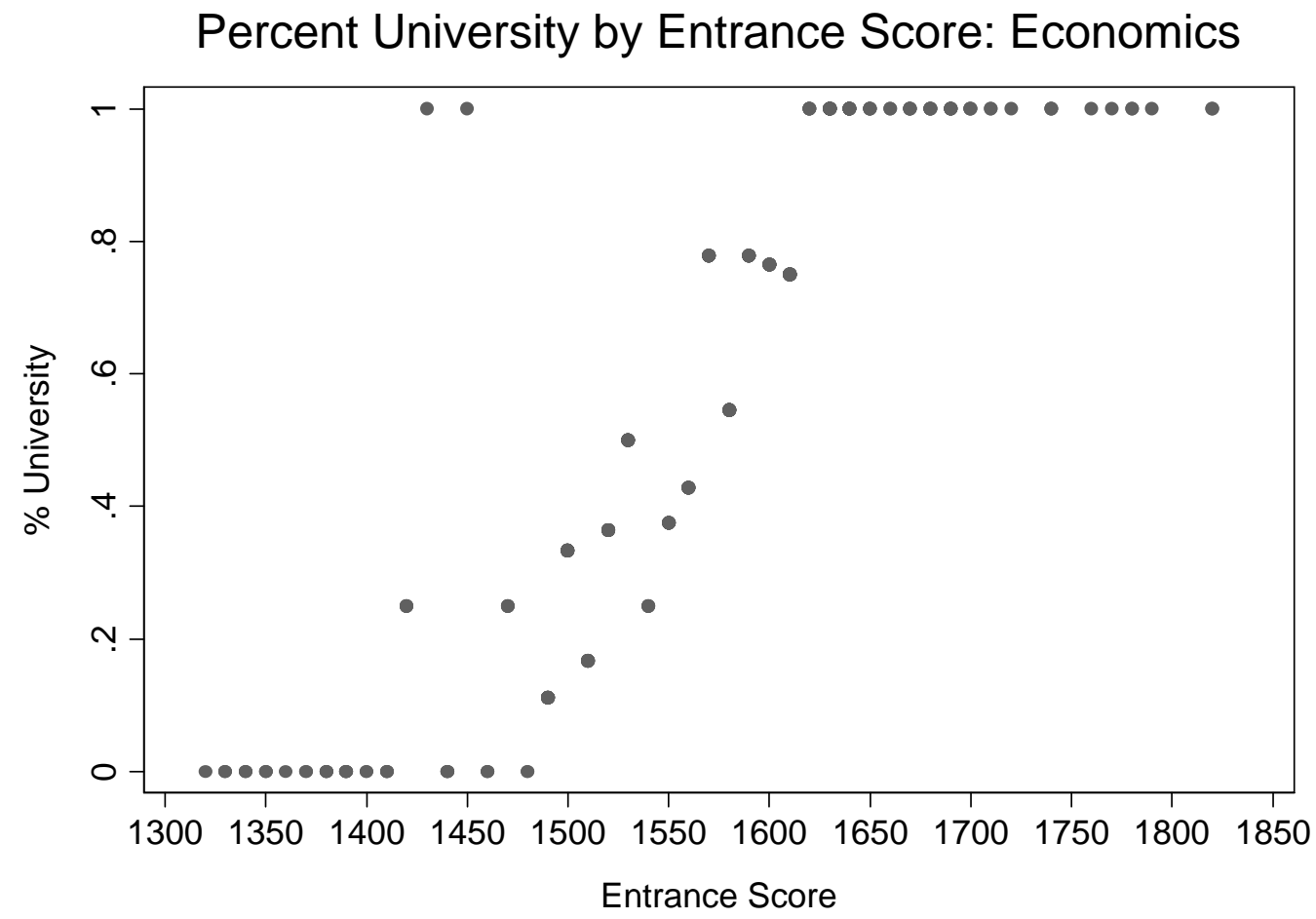


Figure 1c

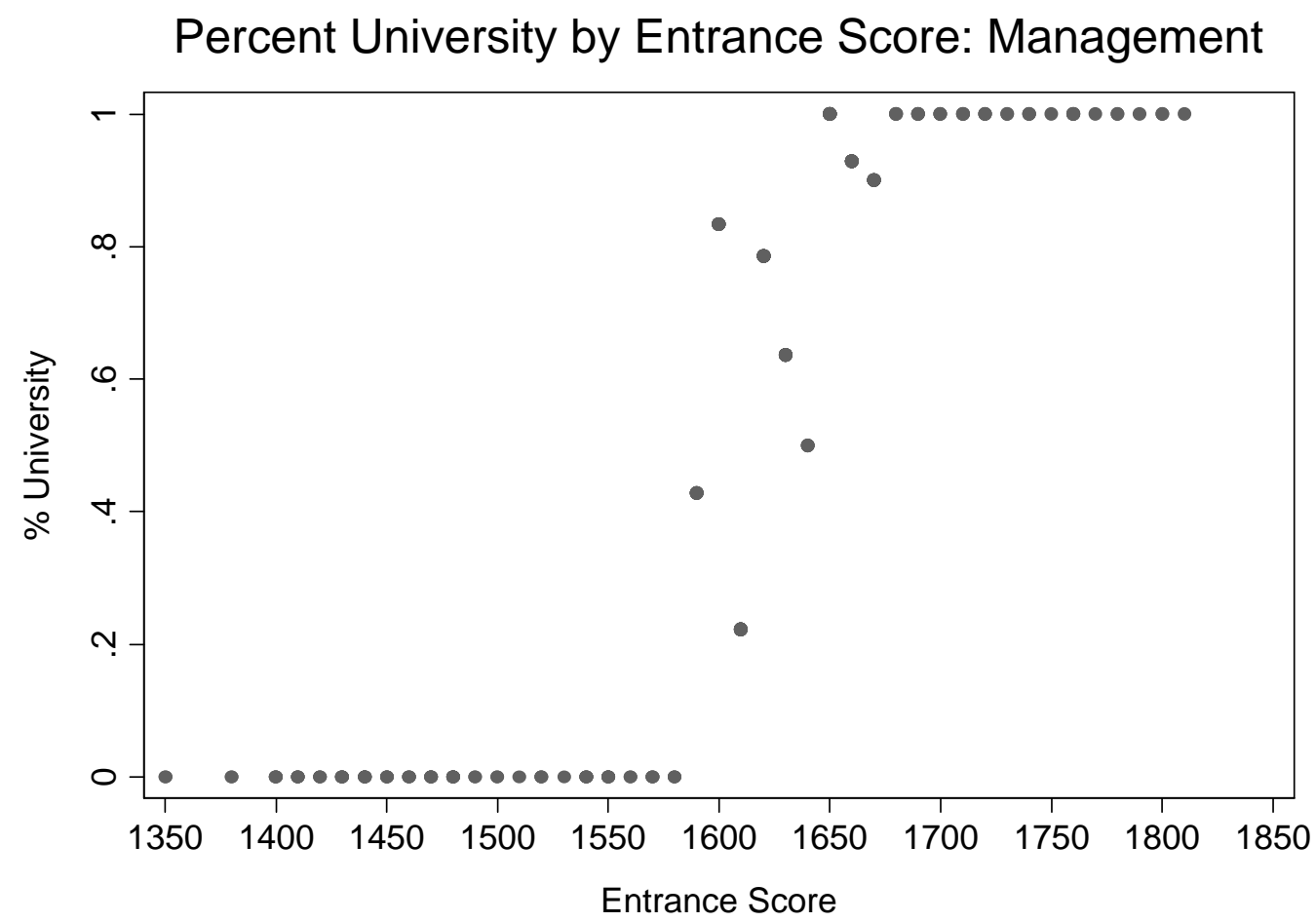

Figure 1d

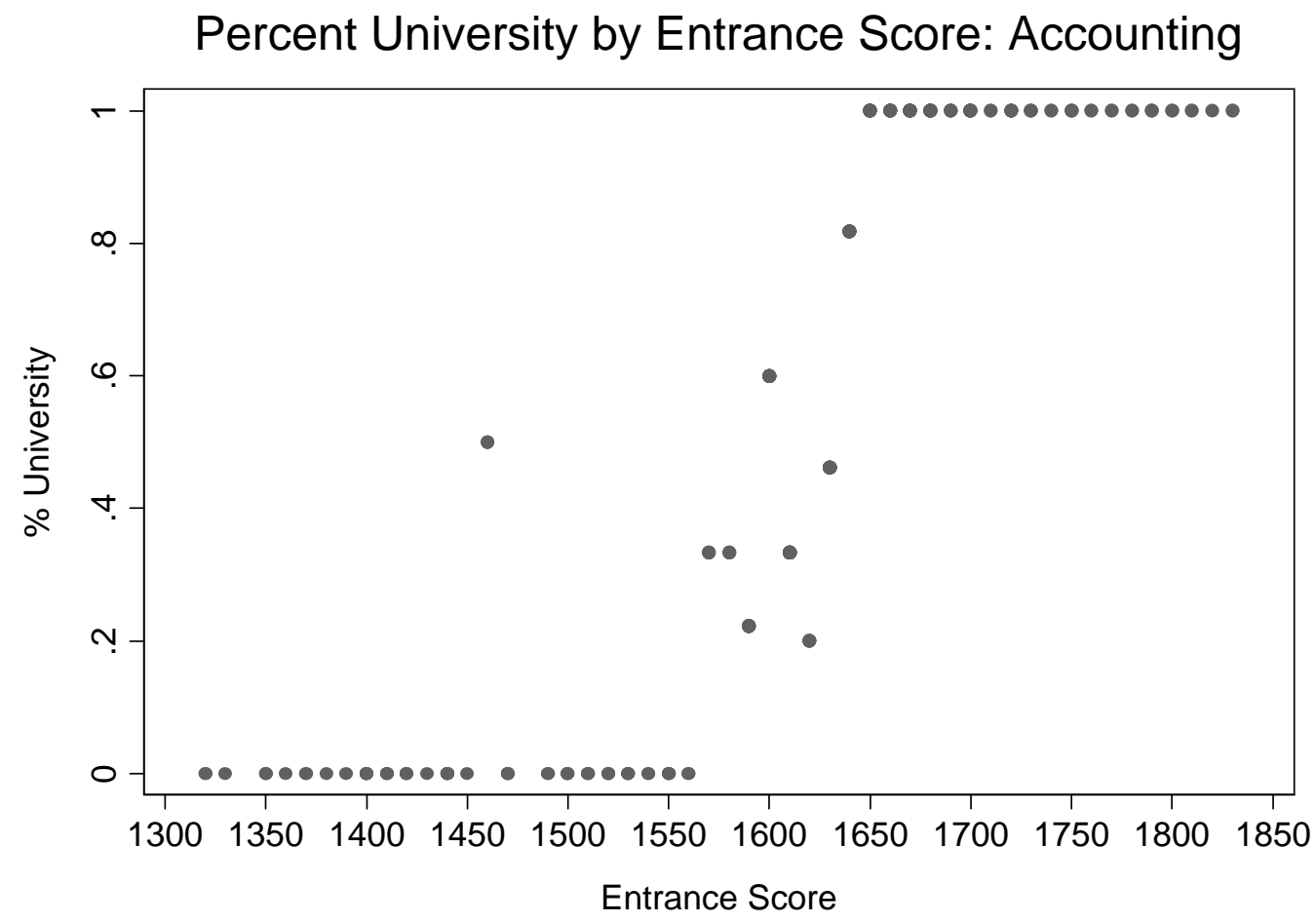


Figure 2a

\section{Log Wage and Entrance Scores After Four Years University v College}

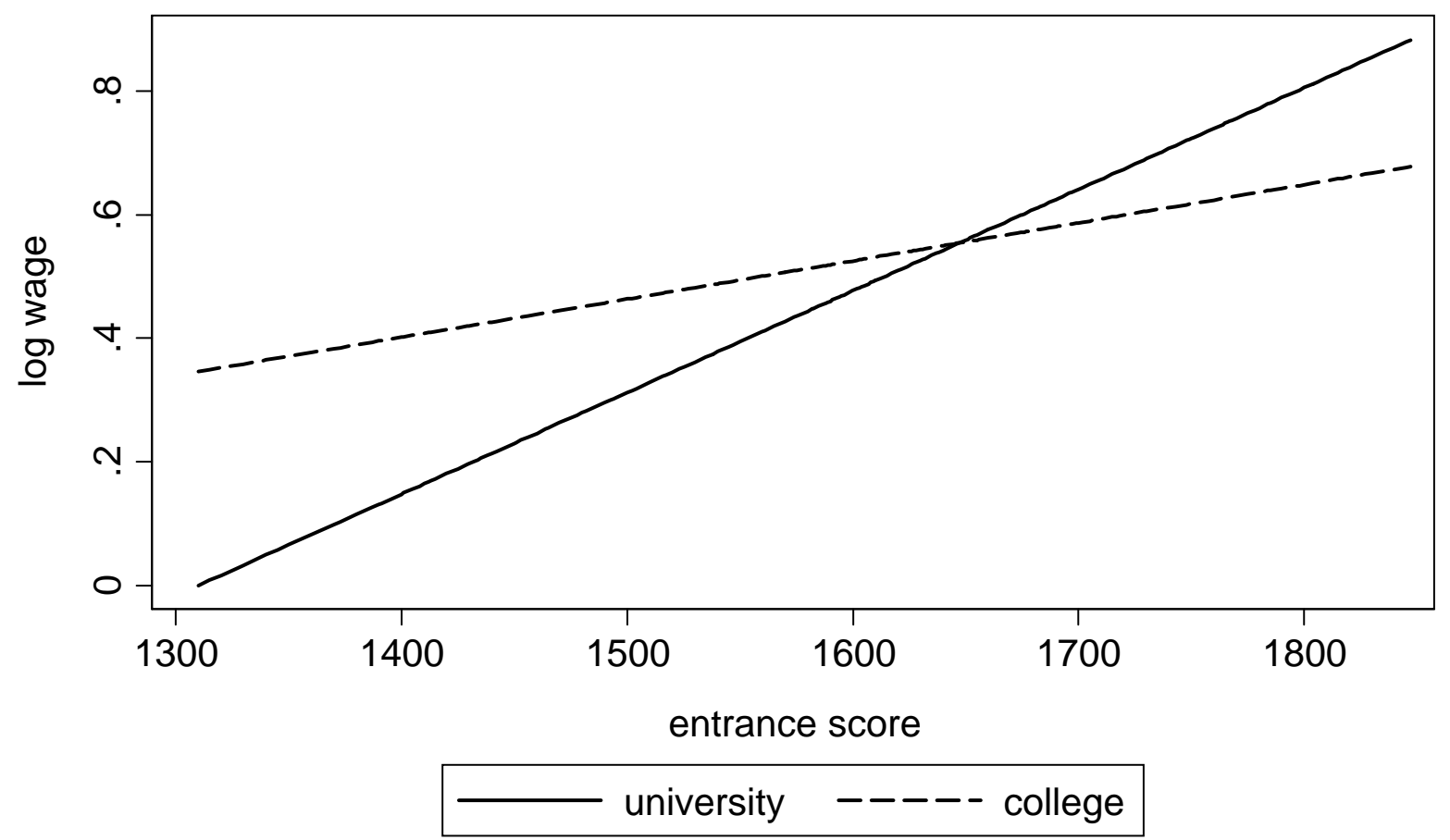

University log wage at lowest entry score is normalized to equal zero. 
Figure $2 b$

\section{Log Wage and Entrance Scores After Seven Years University v College}

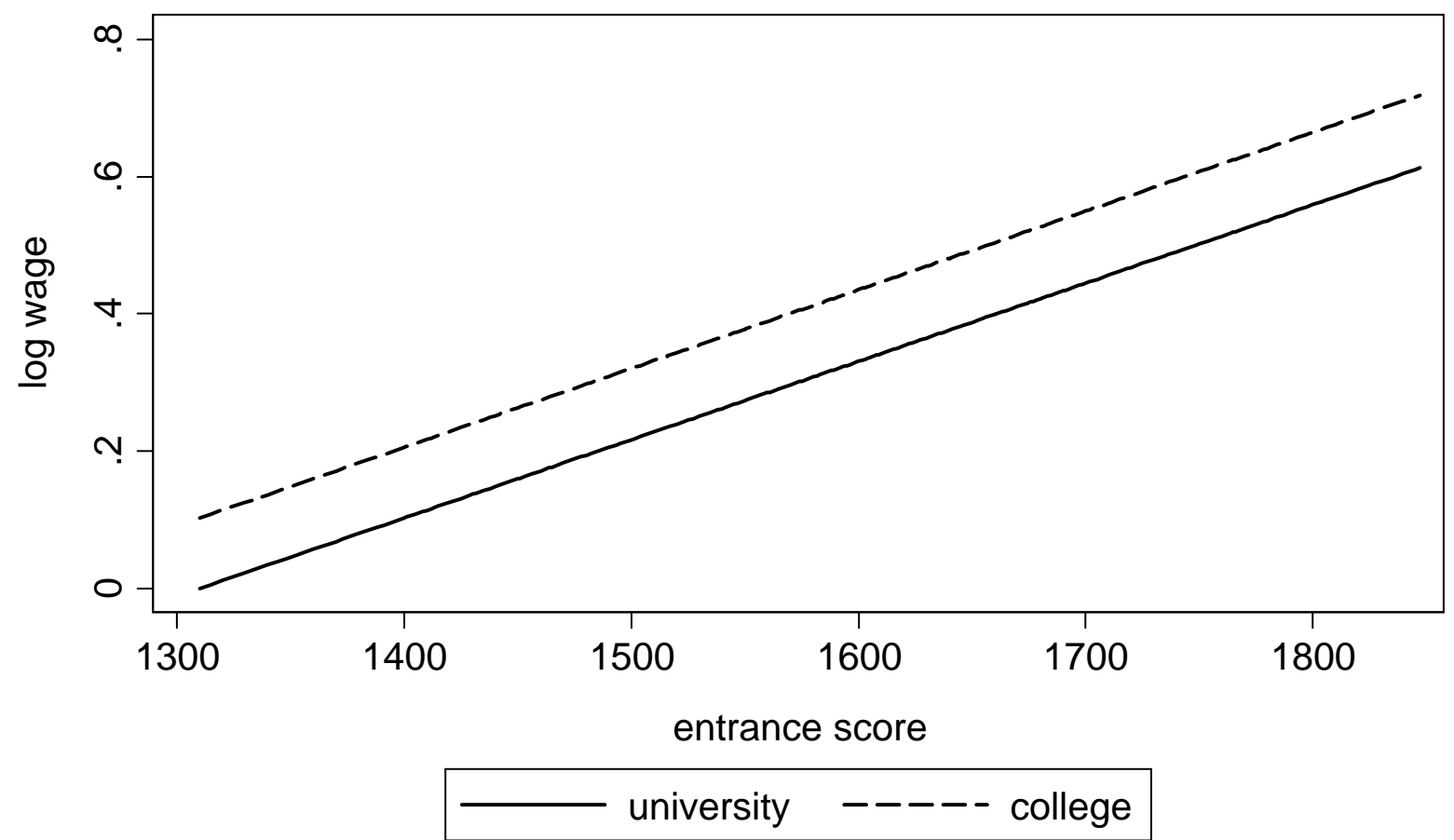

University log wage at lowest entry score is normalized to equal zero. 